\title{
Water governance assessment at different scales: a reservoir case study in the Brazilian semiarid region
}

\section{Avaliação da governança da água em diferentes escalas: um estudo de caso de reservatório na região semiárida do Brasil}

\author{
Aline Pessoa Bezerra ${ }^{1}$ (D), Zédna Mara de Castro Lucena Vieira ${ }^{1}$ (D) \& Márcia Maria Rios Ribeiro $^{1}$ (D) \\ ${ }^{1}$ Universidade Federal de Campina Grande, Campina Grande, PB, Brasil \\ E-mails: alinebezerra2890@gmail.com (APB), zedvieira@globo.com (ZMCLV), marcia.ribeiro@ufcg.edu.br (MMRR)
}

Received: November 19, 2020 - Revised: February 21, 2021 - Accept: April 15, 2021

\begin{abstract}
This article analyses the application of OECD water governance principles to the semiarid region of Brazil. Between 2012 and 2017 , the Paraíba River basin (macroscale) and its Epitácio Pessoa reservoir - EPR (microscale) suffered a severe drought. The reservoir came close to collapse in 2017, which led to water use conflicts that were aggravated due to water mismanagement. Four evaluation criteria were considered: policy alignment to the OECD principles, its implementation, on-ground results, and policy impacts. The outcomes indicate water management fragilities, even after 24 years of the Brazilian National Water Resources Policy enactment, and the need for a better water management integration at different scales: National, State, and River Basin. By considering a smaller scale (a basin and its main reservoir), it was possible to observe water governance failures that lead to water crises since the best practices performed by the national agency, at the national scale, have not been verified at the local scale.
\end{abstract}

Keywords: Brazilian water policy; Epitácio Pessoa reservoir; Governance principles.

\section{RESUMO}

Esse artigo visa a analisar a aplicação dos Princípios da governança da água da OCDE no semiárido brasileiro. De 2012 a 2017, a bacia do rio Paraíba (macroescala), e seu reservatório Epitácio Pessoa (microescala), foram atingidos por uma forte e prolongada estiagem. O reservatório chegou próximo ao colapso em 2017, gerando conflitos pelo uso da água, destacando assim a má gestão de água. Foram considerados quatro critérios de avaliação: alinhamento da política aos princípios da OCDE, sua implementação, efetividade e impactos da política. Os resultados indicam as fragilidades da Política Nacional de Recursos Hídricos, mesmo após 24 anos de implementação, e a necessidade de melhorias na integração das escalas de gestão: Nacional, Estadual e bacia hidrográfica. Considerando uma escala menor (uma bacia hidrográfica e seu reservatório principal) foi possível observar falhas na governança hídrica que levaram à uma crise hídrica em função da agência nacional não ter executado, na escala local, suas melhores práticas.

Palavras-chave: Política hídrica brasileira; Reservatório Epitácio Pessoa; Princípios de governança. 


\section{INTRODUCTION}

Water is in a constant cycle; its availability is variable in quantity and quality and affected by natural variations and human activities (Biswas, 2008). The water resource availability is gradually declining, and the actual water scenario has been called the 'Global Water Crises' (Biswas, 1998; Pahl-Wostl, 2020; Srinivasan et al., 2012; Vörösmarty et al., 2013). However, many water-related problems can be attributed to a governance failure at multiple scales of governance rather than to the resource availability itself. OECD studies have shown empirical evidence on water governance failures, affirming that the current "water crisis" rather than caused by scarcity, is caused by water management and water governance failures (Organization for Economic Co-operation and Development, 2011).

Water governance can be defined as the range of political, social, economic, and administrative systems that regulate the development and management of water resources and provision of water services at distinct scales of society, guiding the resource towards a desirable state and away from an undesirable one. Water management refers to the activities of analyzing and monitoring water resources, as well as developing and implementing measures to keep the state of a water resource within desirable bounds (Global Water Partnership, 2004; Pahl-Wostl, 2017). Regarding water governance issues, the Global Water Partnership - GWP considered the general water governance framework grouped in enabling environment (policies, legislative framework, financing, and incentive structures); defined institutional roles (organizational structure, the capacity of instrument construction), and institutional management (assessment and planning of water resources, demand management, instruments of social change, conflict resolution, regulatory instruments (Global Water Partnership, 2004).

The climate changes extreme events are exposing the vulnerabilities and weaknesses in water management (PahlWostl, 2020). Good water governance is required for good water management, reducing uncertainty risks, and leading to faster and more efficient decision-making (Wei et al., 2018). Governments should support the decentralization of water resources management and governance, assuring local institutions' functioning as well as civil society and water actors' participation, considering the local needs to improve the decision making (Tantoh \& Simatele, 2018).

In 2015, the Organization for Economic Co-operation and Development (OECD) established the 'OECD Principles on Water Governance' with the premise that there is no single solution to all challenges and with the aims of contributing to clear and well-targeted public policies that can serve as a reference for governments (Organization for Economic Co-operation and Development, 2015a). The principles provide a framework to understand whether water governance systems are performing optimally and help to adjust them where necessary (Akhmouch \& Correia, 2016).

An important issue when analyzing a governance process is the scale aspect. Regarding governance scales, Daniell \& Barreteau (2014) have cited seven scales: i) spatial (watersheds/ecosystems; urban areas' catchment); ii) temporal (as in hydrological studies: hours, days, months, years); iii) administrative or jurisdictional (related to administration and the levels they are set up at local, provincial, regional, national, supra-national ones); iv) institutional (which is linked to administrative and spatial scales and is concerned with rules); v) management (this scale is related to the planning activities which can range from tasks at a lower level, to project and programs at mid-level and strategies at a higher level); vi) network (considering the social side: individual, family, community, society, trans-society; and the physical waterside: from water molecules to water droplets, small flows of water, up to more extensive water flows in distribution networks); and vii) knowledge and information (for informing water governance practice at multiple scales, administrative or institutional levels).

In Brazil, there are two water domains (defined by the 1988 Federal Constitution): the federal domain (rivers that cross state or national borders and reservoirs built with federal funds) and the state domain (rivers that run solely within one state territory) (Brasil, 1988). For groundwater management, the state domain is always applied. The awareness of the problems related to water resource scarcity in the country emerged since 1970 in some regions, as a result of industrialization and population growth, causing conflicts among water users (Agência Nacional de Águas, 2017). In 1997, the National Water Resources Policy (PNRH, established by the Federal Water Law 9,433/1997) was enacted as a guide towards achieving good water management. The law defines a robust institutional water management framework to implement an integrated, decentralized, and participatory water management model (Brasil, 1997). However, after 24 years of implementation, scholars and organizations have shown how challenging it is to put the Brazilian Water Policy into practice fully (Neto et al., 2018; Ribeiro, 2017; Agência Nacional de Águas, 2016; Organization for Economic Co-operation and Development, 2015b).

Neto et al. (2018) examined four national water policy frameworks (Australia, Brazil, New Zealand, and South Africa), one transnational water policy framework (Europe), and one global guideline (Lisbon Charter, through the example of Portugal) considering the 12 OECD Principles on Water Governance. Brazilian water policy analysis was performed on a national scale, and the authors concluded that: "The principles of the Brazilian Water Act and the framework for the National Water Resources Management System are well aligned with the OECD principles" and "As the country is so vast and diverse, the current status of implementation and on-ground results varies across the water planning scales". An application of the OECD Water Governance Principle 2 can be found in Assis et al. (2020) for São Francisco River Basin and its sub-basins. In the current paper, we aim to analyze the water governance performance through all the 12 OECD principles in other scales than the national one. Two distinct administrative, institutional, and management scales were considered: a basin-scale (Paraíba River Basin - PRB) and a reservoir scale (Epitácio Pessoa Reservoir - EPR) inserted in the PRB. The PRB and EPR were chosen for the following reasons:

- The Paraíba River basin (macro-scale) is entirely situated within the territory of the State of Paraíba (state domain), and a single state water agency performs its water resources management. Most of the Paraiba River basin area is inserted into the Brazilian semiarid region - a drought-prone area characterized by low average annual rainfall and water storage reservoirs carrying water availability from wetter years to following drier years (Silva et al., 2017; Vieira \& Ribeiro, 
2010) - and presents different rainfall indexes and soil uses along the river bed. These conditions make its water governance and management a more significant challenge;

- The Epitácio Pessoa Reservoir (micro-scale) is inserted in the Paraíba River basin, and it is an important reservoir for the semiarid region of Paraíba State built with federal government funds (federal domain). Hence, a federal water agency performs its management due to the determination of the Brazilian Constitution. The reservoir has suffered the effects of severe and recurrent droughts, so conflicts over water use (urban water supply versus irrigation) have arisen. The drought that plagued the region during the period 2012-2017 led the Epitácio Pessoa Reservoir - the largest in the basin - to operate with its technical reserve. Thus, from 2014 to 2017, approximately 1 million people supplied by the reservoir were subjected to severe water rationing. This situation turned the EPR into one of the most important case studies for the National Water Agency (ANA), responsible for reservoir management (Agência Nacional de Águas, 2017). Despite all the advances achieved after the Brazilian Water Policy implementation, this scenario is an aggravated repetition of the 1998-2000 urban water supply crisis (Rêgo et al., 2017).

\section{The OECD principles on water governance}

Some necessary actions were identified in water management to avoid practice failures, such as: decentralized management approach and decision making, integrate sectors, identify the management problem source, management attention improvement of human behaviors, explicit environment management goals, open-access information, and incorporation of interactive learning cycles into management processes. (Pahl-Wostl, 2020; Pahl-Wostl et al., 2006). Water governance can contribute to water policy implementation, guarantee water security, and improve the countries' socio-economic development (Gurría, 2020).

To evaluate the principle degree of adaption, Pahl-Wostl (2020) affirms that four different aspects need evaluation: adoption of the principle in water policy and framework; and implementation of the principle, its outcomes, and impacts on water resources management practices. Biswas (2008) states that it is also necessary to evaluate the adoption of the principle's effectiveness.

Aiming to achieve good water governance, due to its importance and complexity, the OECD created, in 2015, the 12 Principles on Water Governance. This neutral and flexible framework considers the current countries necessities to improve water governance at multi-levels scales by identifying the articulation failures between management stakeholders, with the premise that there is no single solution to all challenges and with the aims of contributing to clear and well-targeted public policies that can serve as a reference for governments (Organization for Economic Co-operation and Development, 2015a). The Principles should be applied to adjust the water policies to the local reality and to adapt these politics, in case of environmental changes, systematically and inclusively, at all scales of government (Akhmouch et al., 2018). By considering this reason and the fact that those principles are a new adaptive tool, the OECD principles were chosen for evaluating the water governance in this research.

The twelve OECD Principles on Water Governance clustered around three main water governance driving goals defined by the Organization for Economic Co-operation and Development (2015a, 2018): its effectiveness, to establish clear sustainable water policy goals and targets at all scales of government, to implement those policy goals, and to meet expected targets; its efficiency, to maximize the benefits of sustainable water management and welfare at the least cost to society; and its ability to generate trust and engagement, to build public confidence and ensure inclusiveness of stakeholders through democratic legitimacy and fairness for society. Figure 1 shows an overview of these principles.

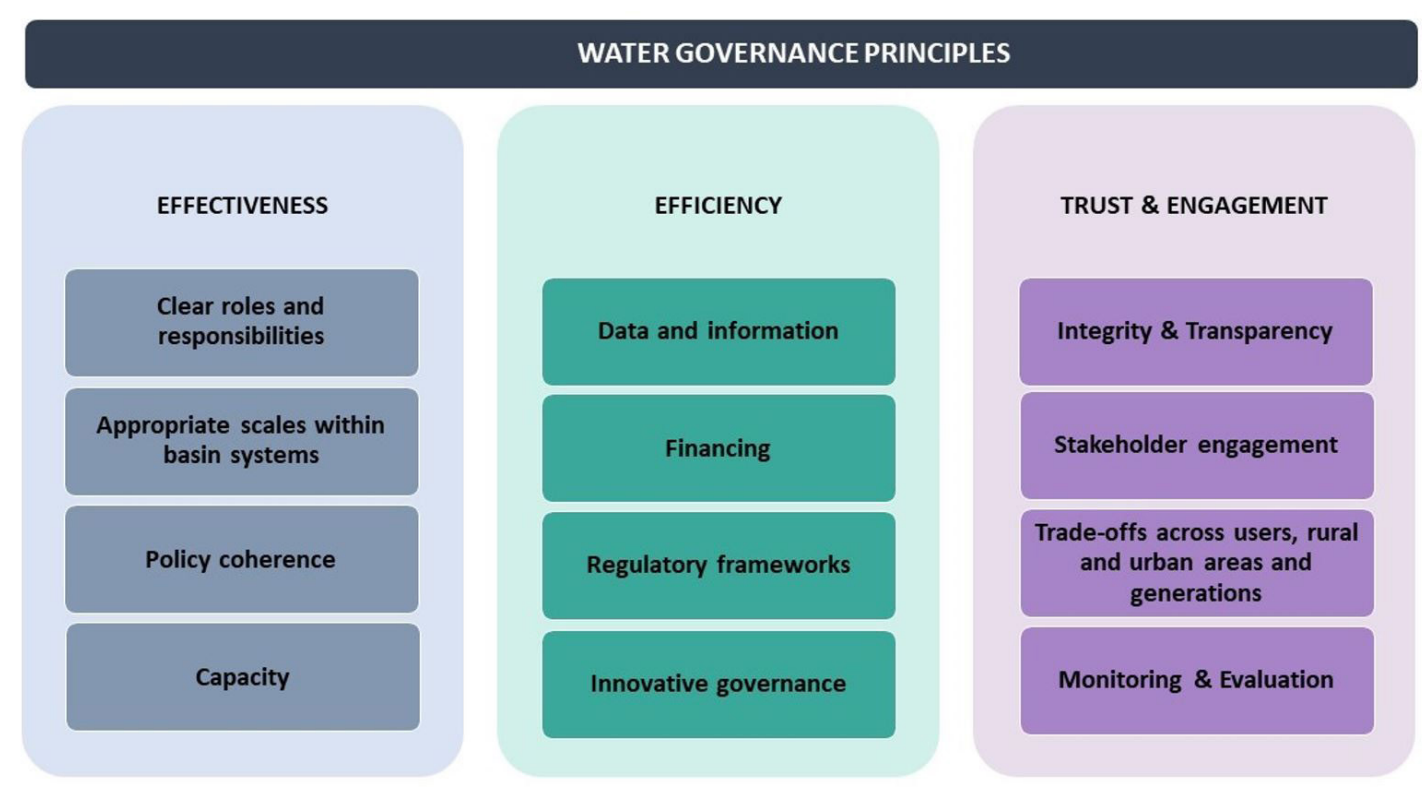

Figure 1. Overview of the OECD water governance principles. Source: Adapted from Organization for Economic Co-operation and Development (2015a). 
Some authors have analyzed water governance systems and contexts, considering the OECD Principles on Water Governance. Colon et al. (2018) showed the French water system's performance and concluded that the system still needs to be improved regarding some principles. Ménard et al. (2018) argued that the OECD Principles on Water Governance are essential steps to overcome some institutional gaps as those in the policy-formulation process and the policy's operationalization. Considering the OECD Principles, Neto et al. (2018) examined six water resources and water services frameworks in Europe, Asia-Pacific, Africa, and South America, including the Brazilian National Water Policy, under four criteria: alignment, implementation, on-ground results, and policy impacts. The authors pointed out that OECD principles primarily focus within national boundaries lacking a mechanism to address transboundary cooperation. Taylor et al. (2019) critiqued the OECD 12 Principles because they assume state authority over water governance. The authors considered the principles to reinforce colonialism's discourse, making invisible Indigenous' people own water governance systems.

\section{Brazilian National Water Resources Policy (PNRH)}

The National Water Resources Policy (PNRH), established by the Federal Water Law 9,433, was enacted in 1997. It has guided the path towards achieving good water governance and management in Brazil. The law defines a robust institutional water management framework to implement an integrated, decentralized, and participatory water management model (Ribeiro, 2017; Agência Nacional de Águas, 2016; Organization for Economic Co-operation and Development, 2015b). The PNRH establishes goals, general guidelines, and instruments for water management in Brazil. Its principles are: (i) water is a public domain good; (ii) water is a limited natural resource, with economic value; (iii) in water scarcity situations, the priority of water use is for human supply and animal needs; (iv) water management resources should always promote multiple uses of water; (v) the river basin is the territorial unit for the PNRH implementation and the National Water Resources Management System (SINGREH) acting; (vi) water resources management must be decentralized and involve public authorities, water users and civil society.

The SINGREH is a set of bodies responsible for water policy formulation and implementation (Figure 2). It is composed of two types of entities. Those who formulate the water policy as the National Water Resource Council (CNRH); State water resource councils (CERH), being one CERH for each Brazilian state; River basin committees (CBHs) which can be under federal or state domain. $\mathrm{CBH}$ are composed of public authorities, water users, and civil society representatives - responsible for promoting discussion and taking decisions on water-related issues in the watershed area and articulating actions of all involved entities. The second type of bodies is those who implement the water policy.

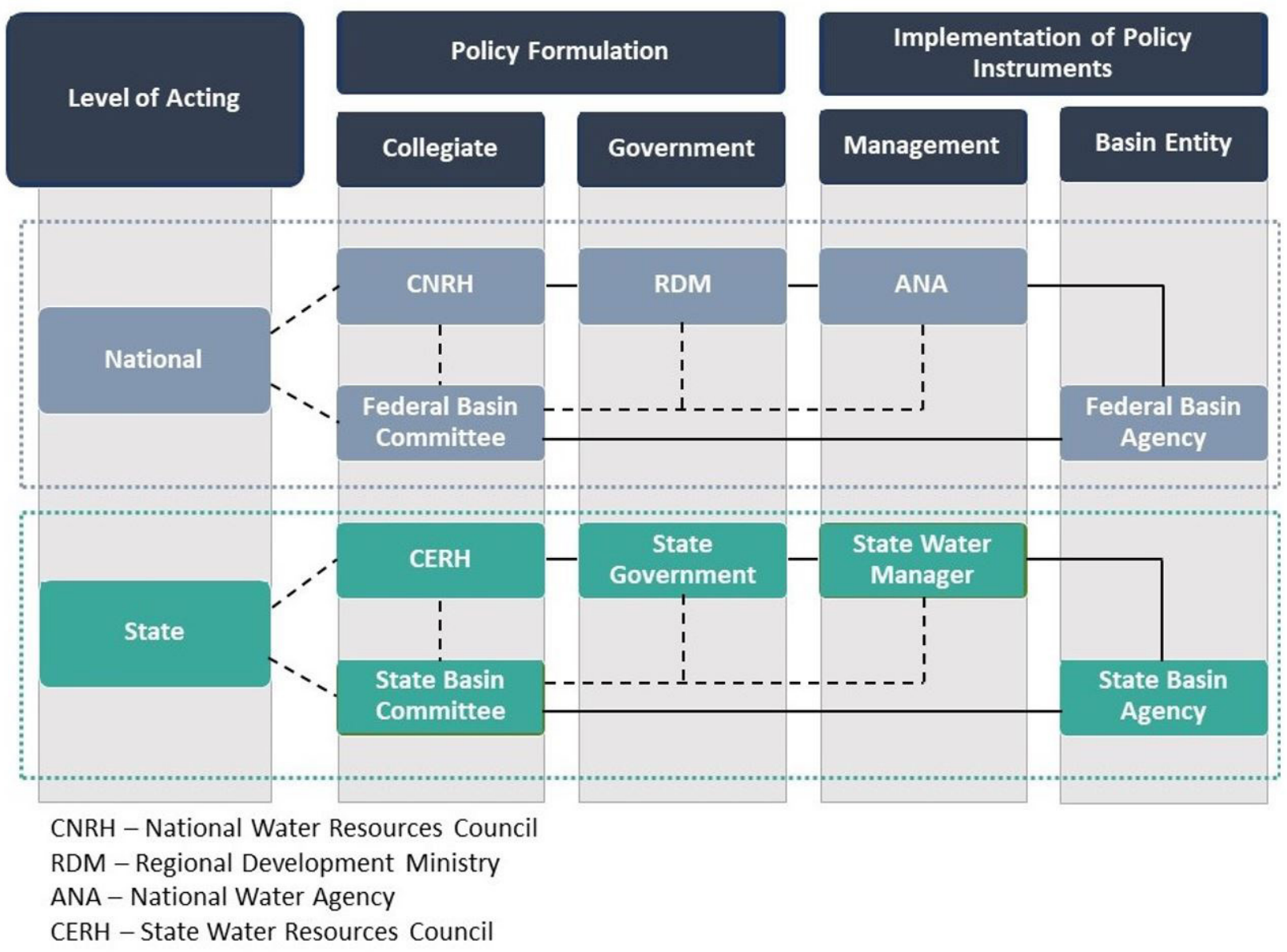

Figure 2. The National System of Water Resources Management (SINGREH). Source: Adapted from Agência Nacional de Águas (2017). 
They are water management agencies: National Water Agency (ANA) and water state agencies, being one for each Brazilian state. These agencies are responsible for supervising, controlling, and evaluating actions and activities that result from the national or state water legislations (Agência Nacional de Águas, 2017). Since January 2019, ANA and the CNRH are no more under the Ministry of Environment due to a new federal government in the country. They belong to the Regional Development Ministry instead. Very recently, ANA changed its name from National Water Agency to National Water and Basic Sanitation Agency due to Law 14,026, enacted in 2020.

Although Brazil is not an OECD member country, in 2015, the ANA and the Ministry of Environment asked OECD to carry out a water resources governance assessment in Brazil. The assessment focused on two key issues: 1) State and Federal policies coordination effectiveness and, 2) the robustness of current resource allocation regimes to face future water resources challenges. As a result, the Organization for Economic Cooperation and Development (2015b) affirms that Brazil has a strong water resources institutional framework, but there is a weak implementation and lack of coordination between water sectors. There are problems in establishing specific priorities and criteria for water resource plans at different implementation levels. This situation causes difficulties to use the plans as a tool to support water management decision-making.

In addition to the OECD studies, the water governance situation in Brazil is being assessed through the OGA Brazil (Water Governance Observatory), which intends to monitor and evaluate the governance practices in Brazil considering five dimensions (WWF-Brazil, 2014):

i. Institutional Environment: quality and effectiveness of the current water laws and its regulation; ii. State Capabilities: coordination between the water management bodies, the bureaucracy, and the use of financial resources;

iii. System management tools: planning, monitoring, and evaluate public policy;

iv. Intergovernmental relations: interactions between the different sectors, the autonomy of bodies and incentive flexibility and innovation;

v. State-Society Interactions: participation channels and public education.

As one can observe, the five dimensions defined by WWFBrazil (2014) contemplates the principles by the Organization for Economic Co-operation and Development (2015a).

\section{CASE STUDY}

\section{The Paraíba River Basin - PRB (macro-scale)}

The PRB has a total area of $20.071,83 \mathrm{~km}^{2}$, is the second largest river basin of the state (but the major one entirely under the state domain). The river basin is subdivided into four regions (Figure 3): The Upper, Middle, and Lower hydrographic regions of the Paraíba River course and the Taperoá River sub-basin. The PRB's water resources management is performed by a state water agency (Water Management Executive Agency - AESA). The two largest cities in the state are located in the basin, João Pessoa (state capital) and Campina Grande.

Most of the PRB area is inserted into the Brazilian semiarid region (Silva et al., 2017; Vieira \& Ribeiro, 2010). Shallow soils above a crystalline basement characterize approximately $80.4 \%$ of the river basin area, implying low groundwater availability and

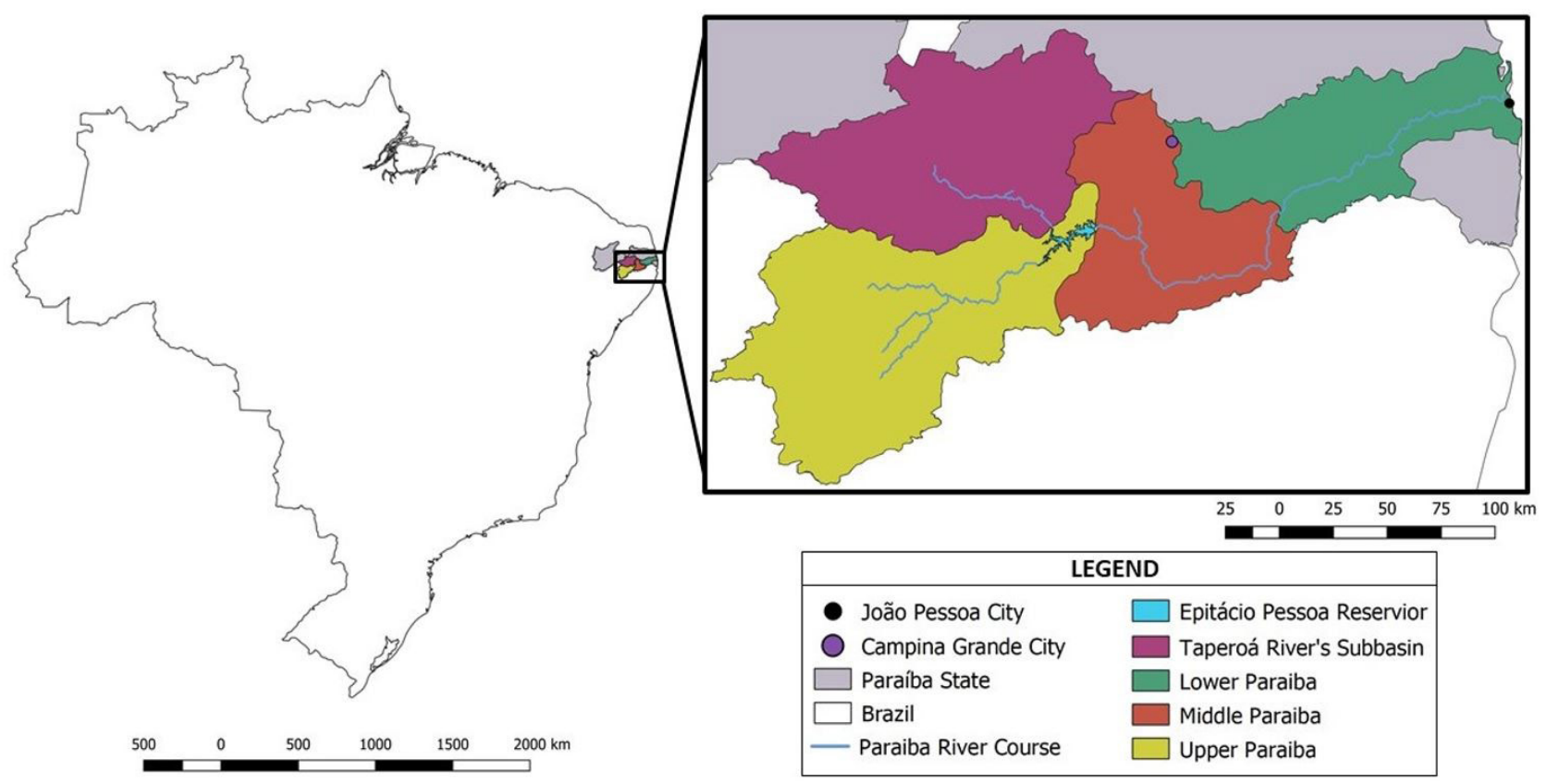

Figure 3. Paraíba River Basin and Epitácio Pessoa Reservoir. Source: Adapted from Agência Executiva de Gestão das Águas do Estado da Paraíba (2018a). 
intermittent rivers, high evaporation rates, significant inter-annual rainfall variability, which imposes sequences of wet and dry years, and recurrent droughts (Medeiros et al., 2011). The basin presents different rainfall indexes and soil uses along the riverbed. The precipitation average rates inferior to $600 \mathrm{~mm}$ per year. According to the Water Stress Indicator (Falkenmark \& Widstrand, 1992), the Paraíba River basin semiarid portion, even when the maximum availabilities considered, is in the 'Water scarcity' range, which becomes a restrictive factor for life.

These conditions make water governance and management more challenging. It is necessary to carry out water from wet to dry years through reservoirs. The basin was characterized by a series of conflicts regarding degradation, extractive activities, elevated scales of sedimentation of the main rivers, and the presence of pottery in the riverbanks. Conflicts are of social and economic nature, especially in drought times (Silva et al., 2017; Ribeiro et al., 2012).

Regarding the Paraíba River Basin Committee (CBH-PB), it was created in 2006, bringing the possibility of decentralized and participatory decision-making. Its plenary is composed of representatives of the Public authorities (30\%), water users (40\%), and civil society (30\%) (Ribeiro et al., 2012).

\section{The Epitácio Pessoa Reservoir - EPR (micro-scale)}

The Epitácio Pessoa Reservoir (EPR), inserted in the PRB, is responsible for supplying 25 cities (Rêgo et al., 2017). The largest one being Campina Grande, an important educational and industrial center with more than 400 thousand inhabitants. The EPR was built with federal government funds from 1951 to 1956 by the National Department for Drought Control (DNOCS), a federal entity, so a federal water agency - the ANA, perform its management. However, its original storage capacity $\left(536,680,000 \mathrm{~m}^{3}\right)$ was reduced to $466,525,964 \mathrm{~m}^{3}$ due to silting. The reservoir has suffered the effects of two severe droughts (1998-2003 and 20122017), so conflicts over water use (urban water supply versus irrigation) have arisen because of water mismanagement.

The EPR regularized discharge is $1.23 \mathrm{~m}^{3} / \mathrm{s}$, defined in the Paraíba Water Resources Plan (Agência Executiva de Gestão das Águas do Estado da Paraíba, 2006). In 1997, a drought cycle began and continued until 2000. In 1999, the reservoir storage scale was near $15 \%$, due to the drought period and excessive withdrawals. As a result, the cities faced severe water rationing, which was only suspended in 2000 when the drought period finished (Rêgo et al., 2013). At that time, DNOCS was the manager of the reservoir and the lands around it.

In 2000, the ANA creation made it responsible for the Epitácio Pessoa reservoir water management, while DNOCS continued as the land manager. In June 2012, ANA granted a $1.3 \mathrm{~m}^{3} / \mathrm{s}$ water permit for CAGEPA (the State water supply company), but the withdrawals were about $1.5 \mathrm{~m}^{3} / \mathrm{s}$ (higher than the value granted). The upstream irrigation withdrawals were considered as insignificant use. However, they represented $0.95 \mathrm{~m}^{3} / \mathrm{s}$ at that time (Rêgo et al., 2014), totalizing a withdrawal of $2.45 \mathrm{~m}^{3} / \mathrm{s}-$ almost twice the official regularized discharge value - increasing the risk of the reservoir's collapse. The irrigation sector used water without permission.

In 2012, a second drought cycle began, and initially, no precautionary measures are taken. The water resources specialists warned about the imminent water crisis if the drought (and the upstream irrigation) continued in the following years (Rêgo et al., 2014, 2017; Silva et al., 2017). The warning led the State Prosecutor's Office to coordinate meetings between the water management agencies (ANA and AESA), water users, specialists, and other public administration sectors, requesting the necessary measures to avoid urban supply collapse. The decisions and events that occurred during this period can be seen in Figure 4.

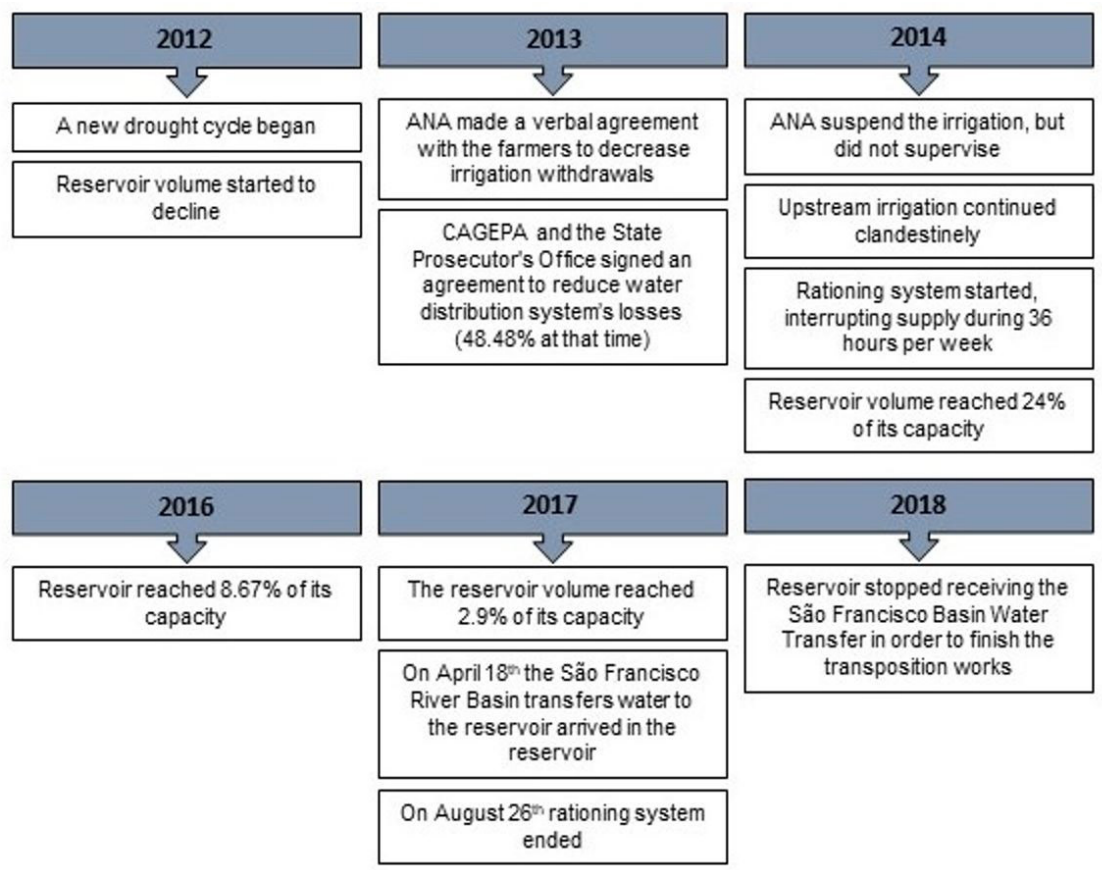

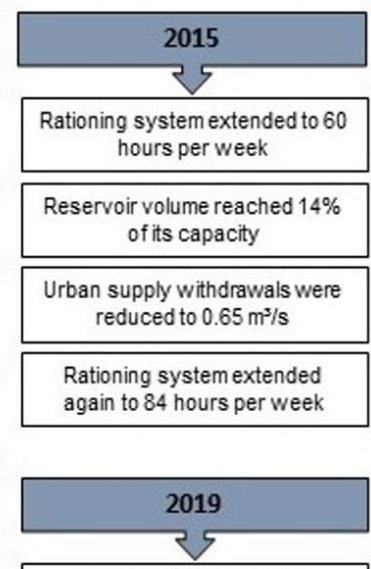

Resumption of the São Francisco Basin Water Transfer supply to the Reservoir in November

Figure 4. Timeline of events occurring during the dry season (2012-2017). Source: Adapted from Rêgo et al. (2017). 
From 2014 to 2017, approximately 1 million people supplied by the EPR were subjected to severe water rationing. Due to the reservoir's low water level in 2016, water abstraction was only possible through floating pumps, exploring the technical reserve (inactive water volume below the withdraw pipes depth), and raising the concern about water quality, which required an additional water treatment due to the elevation of cyanobacteria concentration (Rêgo et al., 2017).

The REP lowest stored volume reached in March 2017: 2.9\% of its total storage. The stored volume evolution of the Epitácio Pessoa reservoir, from 1997 until December 31 2018 , is shown in Figure 5. Considering this context, water was transferred from the São Francisco River Basin. The reservoir crisis arose due to water management failures (as those related to water management instruments) associated with a severe drought period (2012-2017).

\section{METHODS}

The methodology comprises the following steps:

i. Characterization of the study case, at macro and micro-framework analysis scale;

ii. The water governance analysis was based on bibliographical research and official documents issued from 2012 to 2017 related to the case study. The data is available on the ANA and State Water Manager (AESA) official websites. The official documents were: 14 river basin committee's Minutes of meeting; 17 State Water Resources Council's Minutes of meeting; 4 Water Resources Council's resolutions; 11 State Prosecutor's Office Minutes of meeting; 6 ANA and AESA's joint resolutions; 6 AESA's resolutions; the National Environment Law (6,938 of 1981); the National water law (9,433 of 1997); the Paraíba State water Law (6,308 of 1996) (Paraíba, 1996); the National Water Resources Plan (Brasil, 1981, 2006); the Paraíba State Water Resources Plan (Agência Executiva de Gestão das Águas do Estado da Paraíba, 2006); iii. The 12 OECD principles evaluated for the two-scale using four evaluation criteria developed by Neto et al. (2018) (Table 1) as follows: Alignment (A) - refers to the local water policies adaptation and OECD governance principle compatibility; Implementation (I) - OECD governance principle implementation within water policies and management practices; On-ground Results (R) results and efficiency obtained through the governance principle practice; and Policy Impact (PI) - changes observed with the OECD governance principle application on practices or other policies. A Likert scale from 1 to 5 , also developed by Neto et al. (2018), was applied to guide each principle's evaluation.

iv. Based on document analyses and the authors' strong familiarity with the case study, the water governance assessment was performed for the Paraíba river basin (macro-scale) and the Epitácio Pessoa Reservoir (micro-scale).

v. The outcomes allowed the identification of positive aspects and failures. Based on this, recommendations were proposed to achieve good governance.

\section{RESULTS AND DISCUSSIONS}

Table 2 presents the results obtained from the 12 OECD governance principles evaluation, each being analyzed principle at both planning scales, based on the data and official documents, as cited in the methods section. It was applied the values ranging from 1 to 5, as described in Table 1. Comments are made in Table 1 for each principle and planning scale (basin and reservoir). The water allocation process that has been carried out by ANA for the REP (Agência Nacional de Águas, 2019, 2020) was not considered since it occurs after 2012-2017.

The analysis shows that water management in Brazil is well defined, partitioned among the country, state, and water basin scales. For the alignment attribute, the PNRH (law 9,433/97)

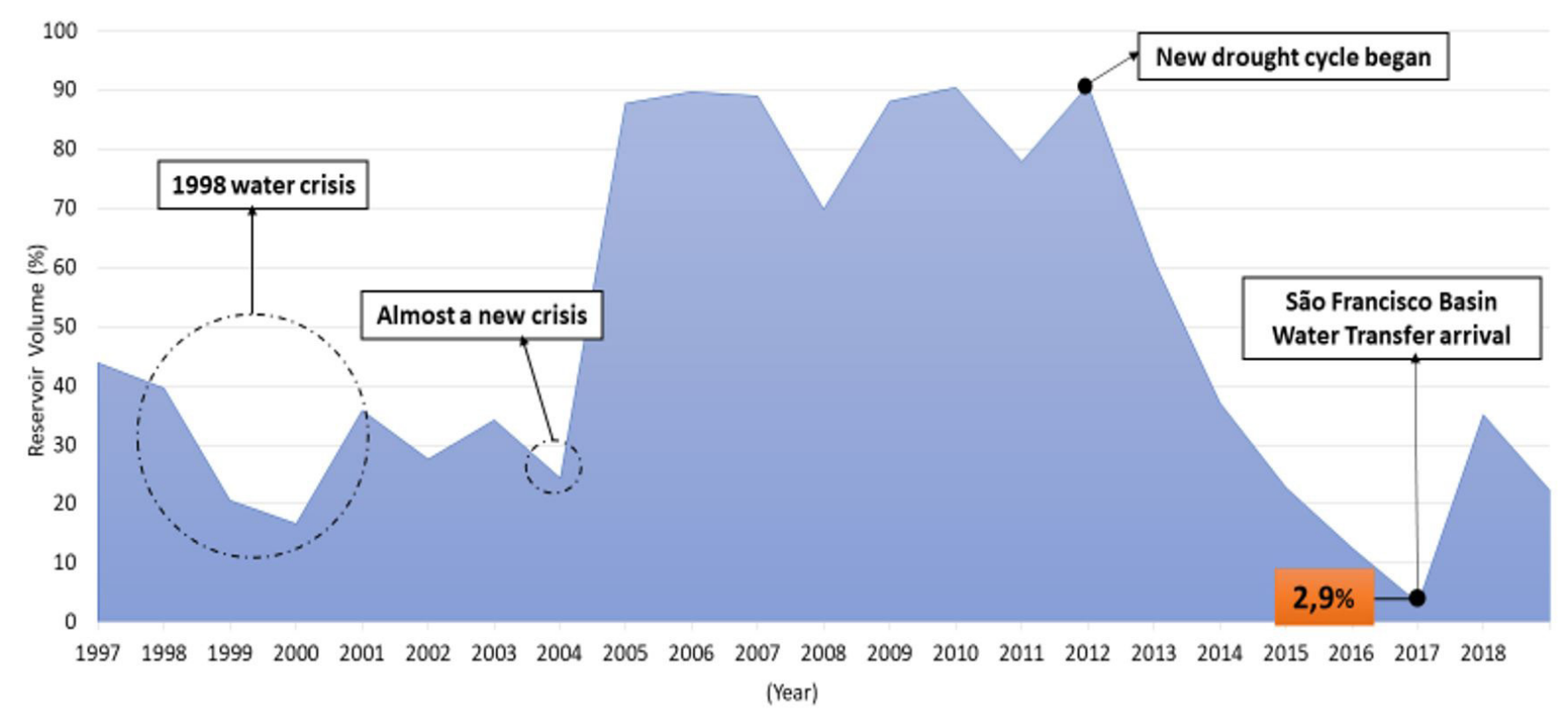

Figure 5. Stored volume evolution of EPR from 1997 to April 2018. Source: Adapted from Agência Executiva de Gestão das Águas do Estado da Paraíba (2018a). 
Table 1. The water governance evaluation criteria matrix by Neto et al. (2018) adopted in this research.

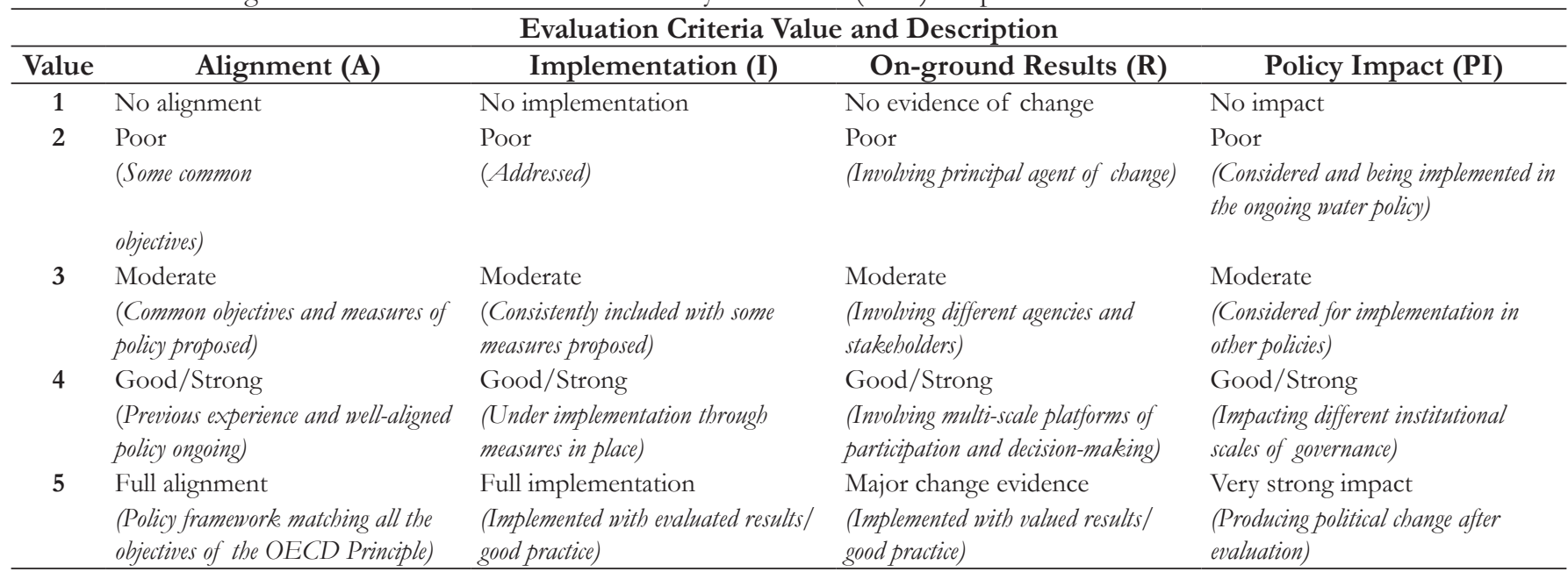

Table 2. OECD principles evaluation, according to the planning and management scales (river basin and reservoir) for the period 2012-2017.

$\begin{array}{cccccc}\begin{array}{c}\text { Planning and } \\ \text { management scale }\end{array} & \text { A } & \text { I } & \text { R } & \text { PI } & \text { Comments }\end{array}$

1. Clearly allocate and distinct roles and responsibilities for water policymaking, policy implementation, operational management and regulation, and foster coordination across these responsible authorities.

\begin{tabular}{|c|c|c|c|c|c|}
\hline Paraíba River Basin & 4 & 3 & 3 & 2 & $\begin{array}{l}\text { Roles are perfectly defined by water laws, but the PNRH (law 9,433/97) } \\
\text { and State (law 6,308/96) don't have all the same management instruments in } \\
\text { common. The coordination performed hierarchically, top-down. }\end{array}$ \\
\hline Reservoir & 5 & 3 & 2 & 2 & $\begin{array}{l}\text { PNRH is well-drafted, with clear roles, but poorly played. Decision-making } \\
\text { centralized by the ANA, reducing on-ground results and policy impact. }\end{array}$ \\
\hline
\end{tabular}

2. Manage water at the appropriate scale(s) within integrated basin governance systems to reflect local conditions, and foster coordination between the different scales.

\begin{tabular}{|c|c|c|c|c|c|}
\hline Paraíba River Basin & 5 & 3 & 3 & 2 & $\begin{array}{l}\text { AES A with good knowledge of local conditions, but the basin committee does } \\
\text { not play its role. Integration, independence, and coordination need to be improved. }\end{array}$ \\
\hline Reservoir & 5 & 3 & 1 & 1 & $\begin{array}{l}\text { The Comitê de Bacia do Rio Paraíba (2015) minutes of meeting shows that } \\
\text { ANA fails in considering local conditions. Water management measures were } \\
\text { adopted only in critical situations (water scarcity) and not continuously. }\end{array}$ \\
\hline
\end{tabular}

3. Encourage policy coherence through effective cross-sectoral coordination, especially between policies for water and the environment, health, energy, agriculture, industry, spatial planning, and land use.

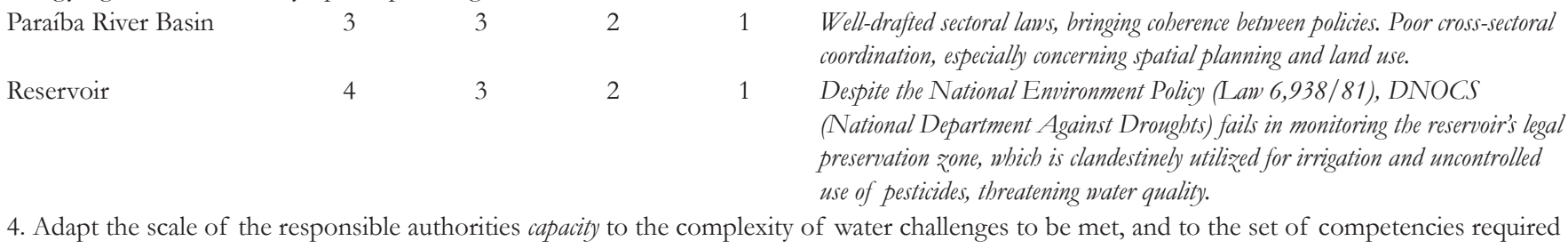
to carry out their duties.

Paraíba River Basin $\quad 4 \quad 3 \quad 2 \quad 2 \quad$ The AES A does not have the necessary infrastructure to implement and supervise management measures (Conselho Estadual de Recursos Hídricos, 2017b), although there are qualified professionals in the Agency.

$\begin{array}{lllll}\text { Reservoir } & 4 & 4 & 3 & 2\end{array}$ The ANA bas well-qualified professionals, but they fail in considering specific knowledge about local conditions (Comitê de Bacia do Rio Paraíba, 2015).

5. Produce, update, and share timely, consistent, comparable, and policy-relevant water and water-related data and information, and use it to guide, assess, and improve water policy.

Paraíba River Basin $\quad 3$

$3 \quad 3$

2 Some information released by the AESA is outdated (especially about water permits and water users); the State Water Resources Plan has not been revised since 2006 (Agência Executiva de Gestão das Águas do Estado da Paraíba, 2018b). Improvement is necessary, referring to information exchange and operational management supervision.

\footnotetext{
Observation: Attributes meaning: A = Alignment; I = Implementation; $\mathrm{R}=$ On-ground Results; PI = Policy Impact. Attributed values' meaning: $1=$ None; $2=$ Poor; 3 = Moderate; 4 = Good/Strong; 5 = Full/Very Strong, as defined by Neto et al. (2018).
} 
Table 2. Continued...

\begin{tabular}{|c|c|c|c|c|c|}
\hline $\begin{array}{c}\text { Planning and } \\
\text { management scale }\end{array}$ & A & I & $\mathbf{R}$ & PI & Comments \\
\hline Reservoir & 4 & 3 & 3 & 2 & $\begin{array}{l}\text { The ANA manages the National Information System on Water Resources, } \\
\text { which is frequently updated, inclusive with data provided by the AESA. Despite } \\
\text { this, it still lacks some essential data, like inspection and water quality. }\end{array}$ \\
\hline \multicolumn{6}{|c|}{ 6. Ensure that governance arrangements help mobilize water finance and allocate financial resources in an efficient, transparent, and timely manner. } \\
\hline Paraíba River Basin & 4 & 3 & 3 & 2 & $\begin{array}{l}\text { Bulk water charges were approved in } 2008 \text { (decree } n^{\circ} 33.612 / 2012 \text { ) and } \\
\text { have been implemented since 2015. However, the basin does not have its water } \\
\text { resources plan yet (Comitê de Bacia do Rio Paraíba, 2017), which hamper } \\
\text { investment allocation. }\end{array}$ \\
\hline Reservoir & 4 & 2 & 1 & 1 & $\begin{array}{l}\text { The Federal government should provide financial resources for any intervention } \\
\text { related to water management. Bulk. water charges implemented in the basin, but } \\
\text { not in the reservoir yet. }\end{array}$ \\
\hline
\end{tabular}

7. Ensure that sound water management regulatory frameworks are effectively implemented and enforced in pursuit of the public interest.

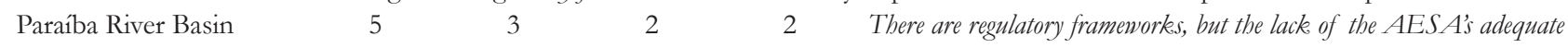
infrastructure makes it challenging to implement it, and there is no river basin agency. The agency fails in controlling water users and water permits.

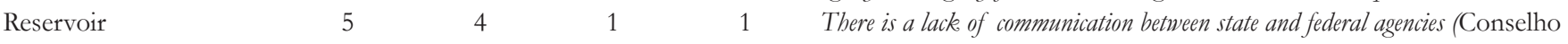
Estadual de Recursos Hídricos, 2014). The AESA, the CBH-PB, and the State Water Resources Council (CERH) don't get involved in the reservoir management properly.

8. Promote the adoption and implementation of innovative water governance practices across responsible authorities, scales of government, and relevant stakeholders.

Paraíba River Basin $\quad 3 \quad 2 \quad 2 \quad 2 \quad$ The CBH-PB should be a forum for innovative practices discussions, but it is strongly dependent on the AESA (Comitê de Bacia do Rio Paraíba, 2015), both technically and financially.

$\begin{array}{llllll}\text { Reservoir } & 5 & 3 & 3 & 2 & \text { According to PNRH (Brasil, 1997), the water agencies are responsible for finances }\end{array}$ water-related studies, the crises stimulated several studies and strategies as those of water loss reduction in the water supply system and the adoption of different water treatment techniques.

9. Mainstream integrity and transparency practices across water policies, water institutions, and water governance frameworks for greater accountability and trust in decision-making.

Pará́ba River Basin 4 rasion

$2 \quad 2 \quad$ Federal and state jurisdictions within the basin do not help integrity and transparency practices, despite the clear rules established by water laws. Lack of transparency makes it difficult to analyze the basin's water management.

Reservoir

4

2

1

The ANA centralizes decision-making over the reservoir's problems. Lack of clear accountability and control mechanisms generates poor transparency practices and trust in the decision-making.

10. Promote stakeholder engagement for informed and outcome-oriented contributions to water policy design and implementation.

$\begin{array}{lllll}\text { Paraíba River Basin } & 4 & 3 & 2 & 2\end{array}$ The river basin committee presents sound functioning failures and is absent from the water management responsibilities, which hamper stakeholder engagement and contributions.

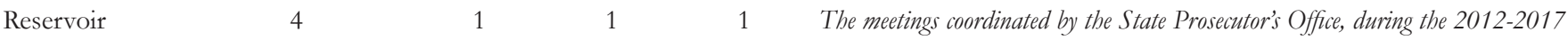
supply crisis were essential to making decisions. Stakeholders only had a few discussions about the reservoir's problems.

11. Encourage water governance frameworks that help manage trade-offs across water users, rural and urban areas, and generations.

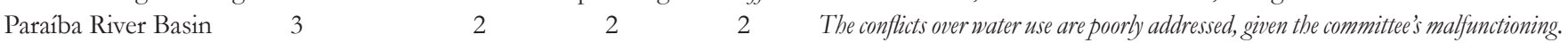

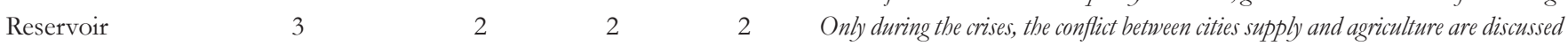
in the CBH-PB meetings. After the return of irrigation withdrawals, the farmers needed to use more efficient irrigation techniques.

12. Promote regular monitoring and evaluation of water policy and governance where appropriate, share the results with the public and make adjustments when needed.

Paraíba River Basin 3

$2 \quad 2 \quad 1$

The CERH is responsible for monitoring and evaluating water policy. The monitoring of the water policy and other measures implementation are discussed in the CERH meetings, but improvements are required.

Reservoir

3

2

2

2

ANA and the CNRH are responsible for monitoring the PNRH and create complimentary water resources guidelines for water management instruments. However, there isn't regular and independent monitoring and evaluation of the water policy as a whole (Comitê de Bacia do Rio Paraíba, 2015).

Observation: Attributes meaning: A = Alignment; I = Implementation; $\mathrm{R}$ = On-ground Results; PI = Policy Impact. Attributed values' meaning: 1 = None; 2 = Poor; 3 = Moderate; 4 = Good/Strong; 5 = Full/Very Strong, as defined by Neto et al. (2018). 
and State (law 6,308/96) legislations are well elaborated. The legislation clearly defines the roles to be played by the different water organisms and establish a water management model that considers participatory and a decentralized decision-making process. The water state law still has some divergences when compared to the national water law. The state law does not consider two of five management instruments found on the national water law: the system for classification of water bodies according to their water quality and the water resources information system (Principle 1).

The PNRH establishes three different scales for water management: national, state, and river basin scale. Both laws consider local conditions and characteristics regarding those scales (Principle 2).

The laws establish a robust and well-planned water resources management regulatory framework. Institutions have their functions and responsibilities delimited in the law (Principle 7). They can promote integrity and transparency practices through coordination between the policymakers and integrated water resources management bodies (Principle 9). The creation of the State Water Resources Council (CERH) and Basin Committees, allows considering different points of view into the policy formulation (Principle 10). This situation leads to consider interests among users, seeking to improve the meeting of everyone's needs, and encouraging integrated water resources management with environmental management and land use (Principle 3). At the state level, the law does not contemplate the existence of a river basin agency (a professional body to help the basin committees technically) and the AESA also plays this role. This situation may not be considered inappropriate when there are financial difficulties in setting up a river basin agency. However, it can generate centralization of the management process. These points (Table 1) results in general high scores for the Alignment criterion, indicating that the case study has a strong legal base to achieve good governance.

The policy implementation, however, presents several problems. Although the roles and responsibilities are clear, there are challenges to be overcome. The distinct jurisdiction defined by the Brazilian Federal Constitution (Brasil, 1988) establishes federal authority over waters stored in reservoirs built with federal financial resources, which makes the ANA the EPR water manager. On the other hand, Law 9,433/1997 determines that the river basin is the territorial unit to implement water policy and the lowest scale for water management. Considering this, the AESA is the manager for the basin since Paraíba River runs solely within the territory of the Paraíba State. Regarding the CBH-PB, it must act within this basin (Principle 2).

In practice, ANA is the only reservoir's water management, not taking into account the existence of the $\mathrm{CBH}-\mathrm{PB}$ during the period of analysis (2012-2017) and creating a top-down and centralizing power and decision-making. At the basin scale, AESA is: (i) the state water manager; (ii) the executive secretary of the CERH; (iii) acts as the CBH-PB's basin agency, which makes it responsible for elaborating technical studies (including the basin's water plan) and implementing/collecting bulk water charges; and (iv) is the manager of the State Water Fund, concentrating financial resources (Principle 1).
The coordination between sectors is not often included in management decisions. There is a lack of relationship between representants in the CBH-PB and the CERH minutes of meetings (Principle 3). In practice, ANA is the REP's water manager, not taking into account the existence of CBH-PB (Principle 7). There was inconsistency in exchange information about water withdrawals and water users' registration between ANA and AESA (Principle 5). During the water crisis, ANA's lack of communication and transparency with $\mathrm{CERH}$ and $\mathrm{CBH}-\mathrm{PB}$, releasing information about the REP not consistent with the real situation (Principle 9). The agency did not take innovative measures to face the crisis but restrictive emergency ones only (Principle 8).

AESA has qualified technical staff, but not enough for attending to its needs (Principle 5). The CERH holds meetings regularly, every 90 days. The $\mathrm{CBH}-\mathrm{PB}$, on the other hand, holds semiannual meetings and extraordinary meetings according to necessity. Some of the meetings have been canceled due to a lack of a quorum (Principle 10). The CBH-PB has no autonomy and not organized enough to be independent of AESA. Society's recognition of the water-related agencies is very low; most of society does not recognize their existence (Principle 11). All these presented points result in lower scores for the Implementation criterion.

The policy implementation influences the on-ground results of the principle, state regulatory management framework does not function adequately due to a lack of physical infrastructure. The $\mathrm{CBH}-\mathrm{PB}$ had little participation and weak influence on decisionmaking during the crisis (Principle 7). Its members themselves have assumed the lack of discussions about the PRB and the REP problems in the meetings, omitting their responsibilities (Principle 10).

Although AESA is well aware of basin water conflicts, it doesn't have enough qualified staff for monitoring all the basins (Principle 4). ANA is not familiar with the river basin's needs and conflicts, failing to make preventive decisions, disregarding the region's vulnerability (Principle 2). The irrigators showed concern about the critical level of the REP. As a result, irrigator associations became more organized and increased participation in the water management process (Principle 11). Those facts affect the On-ground Results criterion score directly.

The crisis increases water agencies' awareness about roles and responsibilities (Principle 1), strengthening the interaction between ANA and AESA, generating a positive impact in regional water policy implementation. However, it was not possible to observe in the documents how the REP management should be carried out (Principle 2).

The adherence to PROCOMITÊS (Conselho Estadual de Recursos Hídricos, 2017a) and to PROGESTÃO (Agência Nacional de Águas, 2013), which are federal financial government programs, induces changes in water policy implementation due to the program's goals requirements to receive financial funds (Principle 6). Those programs have as goals: staff training (Principle 4), finance innovative policies, scientific research and technology (Principle 8), encourages integrity, transparency, and communication between water management bodies (Principle 9), improving the committee operational capacity (Principle 10), updating and sharing data (Principle 5). 
Some positive impacts were observed, such as new water treatment, research about the water quality effects on the population health, and investment to reduce water system loss (Principle 8). Other impacts are: better participation of the irrigators in the CBH-PB meetings in the 2015-2018 period, adoption of more effective irrigation techniques, rising of the population water waste awareness (Principle 11), and water-related data revision, such as irrigators and user registration (Principle 5). However, these impacts do not reach institutional levels, which for the Policy Impact criterion, according to Table 1, was equivalent, in general, to score 2 .

The critical situation periodically experienced by the REP is a major example of some water governance fragilities: the interference of federal or state prosecutors have always been necessary to guarantee the adoption of adequate water management measures. Due to these governance fragilities, especially the delay in decision-making, the São Francisco River basin water transfer became the only alternative to prevent the REP's total collapse.

\section{CONCLUSION}

This research assessed the water governance through the lens of the 12 OECD water governance principles for the Paraíba River Basin and its Epitácio Pessoa Reservoir, considering the period of 2012 to 2017. Four different evaluation criteria were applied.

For the Alignment criterion, the best scores were obtained due to the well planned federal and state institutional frameworks, covering all the 12 OECD principles on water governance, focusing on getting decentralized water management, with public participation of water users and the civil society. The scores dropped in for the Implementation criterion for several reasons. Among them, the water resources management agencies fail to exercise properly their functions established by law. There are flaws in considering local climatic conditions on the decision-making, lack of sufficient investment in law enforcement, centralization of decision-making in the ANA's hands. These aspects have a direct influence on the On-ground Results criterion score, presenting generally low scores. The Brazilian semiarid region's climatic characteristics require constant monitoring of the water's quality and quantity and quick and efficient decision-making in drought periods. For the Policy Impact criterion, it was found the lowest scores, even though changes have been observed in the current measures and policies. It was not found effective cross-sectorial coordination between water, the environment, spatial planning and land use.

The research identified a poor performance of the $\mathrm{CBH}-\mathrm{PB}$, resulting in decisions made without significant participation of society which helps increasing conflicts among the multiple uses of water and centralizing the decision-making. Different agencies manage the PRB and the REP, but it must be considered that decisions made at the basin scale interfere with the reservoir's functionality.

To avoid further water supply system crises, many adjustments in management and effective solutions to the basin water resource problems will be necessary. Some key issues to be handled are: the strengthened of the basin committee autonomy; the agencies (both national and state) must be aware of their responsibilities; revision of policy instruments and laws to rectify inconsistencies; improvement in the interaction between ANA, AESA, and the $\mathrm{CBH}-\mathrm{PB}$; monitoring water withdrawal and demand, even in the rainy season; creating a reliable database for fast and efficient decision making; update the State Water Resources Plan; elaboration of the PRB Plan to ensure multiple and sustainable water use.

The arrival of São Francisco River Basin water transfer avoided the total collapse of the REP. This, however, does not exclude the possibility of new water crises. Very recently, a water allocation process has been carried out by ANA for the REP (Agência Nacional de Águas, 2019, 2020) considering such water transfer. This process may represent a turning point for the REP water resources management, and further research must take it into account.

Clear goals, efficient and decentralized institutions are conditions in order to achieve stronger commitment among water actors. In this research, through a smaller scale (a basin and its main reservoir), it was possible to observe problems that a governance evaluation performed on a country as a whole could not identify. Specific issues that are preventing the study area from achieving good governance and avoiding new water crises reinforce the importance of distinct scales for water governance evaluation.

\section{ACKNOWLEDGEMENTS}

The first author received a grant from the CAPES Foundation during her master course at Universidade Federal de Campina Grande (UFCG).

The research is part of the project "Governança de Água: análise e avaliação em contexto de múltiplas escalas e dupla dominialidade" funded by CNPq (Process 421877/2018-9). The authors thank the support of all institutions.

\section{REFERENCES}

Agência Executiva de Gestão das Águas do Estado da Paraíba - AESA. (2006). Plano Estadual de Recursos Hídricos - PERH-PB: relatório final (67 p.). João Pessoa: SECTMA.

Agência Executiva de Gestão das Águas do Estado da Paraíba - AESA. (2018a, 17 de janeiro). Retrieved in 2018, January 17, from http://siegrh.aesa.pb.gov.br:8080/aesa-sig/

Agência Executiva de Gestão das Águas do Estado da Paraíba AESA. (2018b, 19 de outubro). Convênio para atualização do plano estadual de recursos hídricos da paraíba é prorrogado. Retrieved in 2020, February 2, from http://www.aesa.pb.gov.br/aesa-website/2018/10/19/ convenio-para-atualizacao-do-plano-estadual-de-recursos-hidricosda-paraiba-e-prorrogado/

Agência Nacional de Águas - ANA. (2013). Avaliação das metas de gestão de águas no âmbito do sistema estadual em 2013 - PROGEST ÃO. Paraíba: CERH/AESA.

Agência Nacional de Águas - ANA. (2017). Brazilian Water Resources Report - 2017: full report. Brasília: ANA. 
Agência Nacional de Águas - ANA. (2019). Termo de alocação de água 2019/2020 - Sistema Hídrico Epitácio Pessoa. Brasília: ANA.

Agência Nacional de Águas - ANA. (2020). Termo de alocaşão de água 2020/2021 - Sistema Hidrico Epitácio Pessoa. Brasília: ANA.

Agência Nacional de Águas - ANA. (2016). Brazilian Water Resources Report - 2016: full report. Brasília: ANA.

Akhmouch, A., \& Correia, F. N. (2016). The 12 OECD principles on water governance - When science meets policy. Utilities Policy, 43, 14-20. http://dx.doi.org/10.1016/j.jup.2016.06.004.

Akhmouch, A., Clavreul, D., \& Glas, P. (2018). Introducing the OECD principles on water governance. Water International, 43(1), 5-12. http://dx.doi.org/10.1080/02508060.2017.1407561.

Assis, W. D., Ribeiro, M. R., \& Silva, S. R. (2020). Multi-level governance application to a shared river basin. Revista Brasileira de Recursos Hídricos, 25(44), e44. http:/ / dx.doi.org/10.1590/23180331.252020190164.

Biswas, A. K. (1998). Deafness to global water crisis: causesand risks $A M B I O, 27(6), 492-493$.

Biswas, A. K. (2008). Integrated water resources management: is it working? International Journal of Water Resources Development, 24(1), 5-22. http:/ /dx.doi.org/10.1080/07900620701871718.

Brasil. (1981, 2 de setembro). Lei no 6.938, de 31 de agosto de 1981. Dispõe sobre a Política Nacional do Meio Ambiente, seus fins e mecanismos de formulação e aplicação, e dá outras providências. Diário Oficial [da] República Federativa do Brasil, Brasília.

Brasil. (1988, 5 de outubro). Constituição da República Federativa do Brasil de 1988. Diário Oficial [da] República Federativa do Brasil, Brasília.

Brasil. (1997, 9 de janeiro). Lei no 9.433, de 8 de janeiro de 1997. Institui a Política Nacional de Recursos Hídricos. Diário Oficial [da] República Federativa do Brasil, Brasília.

Brasil. Ministério do Meio Ambiente-MMA. (2006). Plano Nacional de Recursos Hidricos: resumo executivo. Brasília.

Colon, M., Richard, S., \& Roche, P. A. (2018). The evolution of water governance in France from the 1960s: disputes as major drivers for radical changes within a consensual framework. Water International, 43(1), 109-132. http:/ /dx.doi.org/10.1080/025080 60.2018.1403013.

Comitê de Bacia do Rio Paraíba - CBH-PB. (2015, 20 de maio). Ata da $1^{a}$ reunião extraordinária. Campina Grande.

Comitê de Bacia do Rio Paraíba - CBH-PB. (2017, 22 de fevereiro). Ata da $1^{a}$ reunião extraordinária. Campina Grande.
Conselho Estadual de Recursos Hídricos - CERH. (2014, 27 de março). Ata da $33^{a}$ reunião ordinária. João Pessoa.

Conselho Estadual de Recursos Hídricos - CERH. (2017a, 28 de agosto). Resolução no 20, 28 de agosto de 2017. Secretaria de Estado da Infraestrutura dos Recursos Hídricos, do Meio Ambiente e da Ciência e Tecnologia - SEIRHMACT. João Pessoa.

Conselho Estadual de Recursos Hídricos - CERH. (2017b, 24 de março). Ata da $39^{a}$ reunião ordinária. João Pessoa.

Daniell, K. A., \& Barreteau, O. (2014). Water governance across competing scales: coupling land and water management. Journal of Hydrology, 519, 2367-2380. http://dx.doi.org/10.1016/j. jhydrol.2014.10.055.

Falkenmark, M., \& Widstrand, C. (1992). Population and water resources: a delicate balance. Population Bulletin, 47(3), 1-35. PMid:12344702.

Global Water Partnership - GWP. Technical Advisory Committee. (2004). Integrated water resources management (Technical Paper, No. 4). Stockholm.

Gurría, A. (2020). A decade of work on water governance at the OECD: what have we learnt? International Journal of Water Resources Development, 36(2-3), 229-234. http://dx.doi.org/10.1080/07900 627.2019 .1686344 .

Medeiros, S. S., Gheyi, H. R., Galvão, C. O., \& Paz, V. P. S. (2011). Recursos hídricos em regiões áridas e semiáridas. Campina Grande: Instituto Nacional do Semiarido.

Ménard, C., Jimenez, A., \& Tropp, H. (2018). Addressing the policy-implementation gaps in water services: the key role of meso-institutions. Water International, 43(1), 13-33. http:/ / dx.doi. org/10.1080/02508060.2017.1405696.

Neto, S., Camkin, J., Fenemor, A., Tan, P. L., Baptista, J. M., Ribeiro, M., Schulze, R., Stuart-hill, S., Spray, C., \& Elfithri, R. (2018). OECD principles on water governance in practice: an assessment of existing frameworks in Europe, Asia-Pacific, Africa, and South America. Water International, 43(1), 60-89. http:/ /dx.doi.org/10.1 080/02508060.2018.1402650.

Organization for Economic Co-operation and Development - OECD. (2011). Water governance in OECD countries: a multi-scale approach. Paris: OECD Publishing. http://dx.doi.org/10.1787/9789264119284-en.

Organization for Economic Co-operation and Development OECD. (2015a). OECD principles on water governance adopted by the OECD regional development policy committee on 11 may 2015 welcomed by ministers at the OECD ministerial council meeting on June 4th 2015. Paris: OECD Publishing.

Organization for Economic Co-operation and Development OECD. (2015b). Water resources governance in Brazil. Paris: OECD Publishing. http://dx.doi.org/10.1787/9789264238121-en. 
Organization for Economic Co-operation and Development OECD. (2018). OECD Water Governance Indicator Framework. Paris: OECD Publishing.

Pahl-Wostl, C. (2017). An evolutionary perspective on water governance: from understanding to transformation. Water Resources Management, 31(10), 2917-2932. http://dx.doi.org/10.1007/ s11269-017-1727-1.

Pahl-Wostl, C. (2020). Adaptive and sustainable water management: from improved conceptual foundations to transformative change. International Journal of Water Resources Development, 36(2-3), 1-19. http://dx.doi.org/10.1080/07900627.2020.1721268.

Pahl-Wostl, C., Isendahl, N., Möllenkamp, S., Brugnach, M., Jeffrey, P., Medema, W., \& de Vries, T. T. (2006). Paradigms in water management. Osnabrück: NeWater.

Paraíba. (1996, 3 de julho). Lei n 6.308, de 2 de julho de 1996. Institui a Política Estadual de Recursos Hídricos, suas diretrizes e dá outras providências. Diário Oficial do Estado, João Pessoa, PB.

Rêgo, J. C., Galvão, C. O., Albuquerque, J. P. T., Ribeiro, M. M. R., \& Nunes, T. H. C. (2017). A gestão de recursos hídricos e a transposição de águas do Rio São Francisco para o Açude Epitácio Pessoa - Boqueirão. In Anais do XXII Simpósio Brasileiro de Recursos Hidricos. Porto Alegre: ABRH.

Rêgo, J. C., Galvão, C. O., Ribeiro, M. M. R., Albuquerque, J. P. T., \& Nunes, T. H. C. (2014). Novas considerações sobre a gestão dos recursos hídricos do açude Epitácio Pessoa: a seca 2012-2014. In Anais do XII Simpósio de Recursos Hídricos do Nordeste. Porto Alegre: ABRHidro.

Rêgo, J. C., Galvão, C. O., Vieira, Z. M. C. L., Ribeiro, M. M. R., Albuquerque, J. P. T., \& Souza, J. A. (2013). Atribuições e responsabilidades na gestão dos recursos hídricos - o caso do açude Epitácio Pessoa/Boqueirão no Cariri paraibano. In Anais do XX Simpósio Brasileiro de Recursos Hídricos. Porto Alegre: ABRH.

Ribeiro, M. A. F. M., Vieira, Z. M. C. L., \& Ribeiro, M. M. R. (2012). Participatory and decentralized water resources management: challenges and perspectives for the North Paraíba River Basin committee - Brazil. Water Science and Technology, 66(9), 2007-2013. PMid:22925876. http://dx.doi.org/10.2166/wst.2012.414.

Ribeiro, M. M. R. (2017). A few comments on the Brazilian water resource policy. New Water Policy and Practice, 3(1), 22-32. http:/ / dx.doi.org/10.18278/nwpp.3.1.3.2.3.

Silva, C. S., Galvão, C. O., Ribeiro, M. R., \& Andrade, T. S. (2017). Adaptation to climate change: Institutional analysis. In E. Lolokytha, S. Oishi \& R. S. V. Teegavarapu (Eds.), Sustainable water resources planning and management (Chap. 10, pp. 261-279). Singapore: Springer. http://dx.doi.org/10.1007/978-981-10-2051-3.

Srinivasan, V., Lambin, E. F., Gorelick, S. M., Thompson, B. H. \& Rozelle, S. (2012). The nature and causes of the global water crisis: Syndromes from a meta-analysis of coupled humanwater studies. Water Resources Research, 48(10). http://dx.doi. org/10.1029/2011wr011087.

Tantoh, H. B., \& Simatele, D. (2018). Complexity and uncertainty in water resource governance in northwest Cameroon: reconnoitering the challenges and potential of community-based water resource management. Land Use Policy, 75, 237-251. http://dx.doi. org/10.1016/j.landusepol.2018.03.044.

Taylor, K. S., Longboat, S., \& Grafton, R. Q. (2019). Whose rules? A water justice critique of the OECD's 12 principles on water governance. Water, 11(4), 809. http://dx.doi.org/10.3390/ w11040809.

Vieira, Z. M. C. L., \& Ribeiro, M. M. R. (2010). A methodology for first- and second-order water conflicts analysis. Water Policy, 12(6), 851-970. http://dx.doi.org/10.2166/wp.2010.114.

Vörösmarty, C. J., Pahl-Wostl, C., Bunn, S. \& Lawford, R. (2013). Global water, the Anthropocene and the transformation of science. Current Opinion in Environmental Sustainability, 5(6), 539-550. http:/ / dx.doi.org/10.1016/j.cosust.2013.10.005.

Wei, Y., Wang, Z., Wang, H., Yao, T., \& Li, Y. (2018). Promoting inclusive water governance and forecasting the structure of water consumption based on compositional data: a case study of Beijing. The Science of the Total Environment, 634, 407-416. PMid:29627564. http://dx.doi.org/10.1016/j.scitotenv.2018.03.325.

WWF Brazil. Fundação Getúlio Vargas - FGV. (2014). Governance of water resources: proposal of indicators to monitor implementation. Rio de Janeiro.

\section{Authors contributions}

Aline Pessoa Bezerra: Main writer of this article and responsible for the data analysis.

Zédna Mara de Castro Lucena Vieira: Assisted in writing the article, reviewed the article and presented suggestions.

Márcia Maria Rios Ribeiro: Assisted in writing the article, reviewed the article and presented suggestions and supervised the data analysis procedure.

Editor Chefe: Adilson Pinheiro

Editor Associado: Cristóvão Vicente Scapulatempo Fernandes 